\title{
THE EFFECT OF STEAMED TOFU ON SLEEP QUALITY IN PREMENOPAUSAL WOMEN
}

\author{
Munarifah Sulis Widyatiningsih"1) Sri Winarsih ${ }^{2)}$ Christin Hiyana Tungga Dewi \\ Email :Widyasulis55@gmail.com
}

\begin{abstract}
Background: Premenopausal syndrome in the form of hot flushes, night sweats, it can cause sleep disturbances that will affect the quality of the mother's sleep so that the mother wakes up from her sleep. Thus, natural intervention is needed in the form of isoflavone treatment by consuming processed soybeans, namely steamed tofu. The purpose of this study is knowing the effect of giving steamed tofu preparations on sleep quality in premenopausal women in Ngabean Village, Secang District, Magelang Regency

Methods: This type of research is a pre-experimental designs research with One Group Pretest Posttest research design. The measuring instrument used is the PSQI (Pittsburgh Sleep Quality Index) questionnaire. The sampling technique in this research is purposive sampling.

Results: There is a significant effect of the provision of processed steamed tofu on the sleep quality of premenopausal women aged 45-50 years. This is evidenced by the results of the Wilcoxon test with $p$ value $<0.05$.

Conclusion: The sleep quality of premenopausal women aged 45-50 years before consuming processed steamed tofu was found in the majority in the category of poor sleep quality, which was $93.48 \%$ and after consuming processed steamed tofu was found in the majority in the category of good sleep quality, $84.78 \%$. There is a significant effect of the provision of processed steamed tofu on the sleep quality of premenopausal women aged 45-50 years. Suggestion for premenopausal women to consuming variations of processed steamed tofu (2x a day, with a dose of @ 100 grams or medium pieces) as a source of isoflavones in improving the quality of sleep for premenopausal and postmenopausal women who experience sleep deprivation/sleep disorders in the premenopausal period so that they can undergo preage with totality by consuming it regularly
\end{abstract}

Keyword : Premenopausal syndrome; tofu; sleep quality

1,2,3Midwifery Study Program Magelang Poltekkes Kemenkes Semarang

Jl. Perintis Kemerdekaan Kota Magelang, Jawa Tengah, Indonesia

Received: July 18, 2021; Revised: August 16, 2021; Accepted: September 27, 2021

Background. Every human being experiences development and growth over time. But at some point the development and growth will stop at a stage, so there will be many changes that occur in the functioning of the human body. These changes occur in the aging process, because in this process there are many physical and psychological changes. These changes occur mostly in women because in the aging process occurs a phase called the menopause phase (Proverawati \& Sulistyawati, 2017).

According to the World Health Organization (WHO) every year, about 2 million women worldwide are estimated to experience menopause. Who estimates that by 2030 there will be 1.2 billion women over the age of 50. Most (about 80\%) are in developing countries and each year the population of menopausal women increases by about $3 \%$. Of the total population of Indonesia estimated at 240-250 million, there are about 30-40 million elderly women. Almost $100 \%$ have gone through menopause with all its consequences (Achadiat, 2010 in Ida Sriwaty, 2015).

According to the theory (Proverawati \& Sulistyawati, 2017) some women who enter the premenopausal age have difficulty during sleep, they cannot sleep easily or may wake up too early. They may need to go to the bathroom in the middle of the night, then find they can't go back to sleep. Hot flushes can also cause women to wake up from sleep. In addition, difficulty sleeping can be caused by low levels of serotin during pre-menopause. Serotin levels are affected by endorfrin levels.

Intervention programs managing premenopausal signs and symptoms are 
expected to improve the quality of life of premenopausal women. In handling can do activities that can bring relaxed conditions to the body, such as walking every morning and evening, taking a warm bath, or drinking milk before bed (Desi N.T.Idris, Fidiana K, 2016). In addition, it can be by consuming soybeans or processed that contain phytoestrogens in it in the form of isoflavones. Soy isoflavones with a dose of $100 \mathrm{mg}$ can lower LDL and total cholesterol levels, in addition to reducing menopausal symptoms such as difficulty sleeping, Nervousness/ feelings of nervousness, vertigo, palpitations, melancholy and headaches (Widyastuti, 2015)

Isoflavones are a key factor in soy so it has the potential to combat certain diseases. According to the results of the study (Ariyanti \& Apriliana, 2016) with the title "Effect of Phytoestrogens on Menopausal Symptoms" obtained the results that phytoestrogens have the same structure and function as endogenous estrogen. Phytoestrogens can bind to estrogen receptors. Phytoestrogens can increase endometrial thickness, improve elasticity and decrease vaginal $\mathrm{PCl}$, increase bone density, inhibit atherosclerosis, overcome hot flashes, reduce insomnia and improve cognition function. Phytoestrogens can reduce premenopausal symptoms.. In handling can be done by increasing the intake of isoflavones through foods such as processed soy products such as tempeh and tofu (Fawwaz et al., 2017)

Foods made from soybeans have varying amounts of isoflavones, depending on how they are processed. Foods from soybeans such as tofu, soy milk, soy flour and whole soybeans have isoflavones ranging from 80 $100 \mathrm{mg} / 100$ grams of tofu (Aquina \& Permatasari, 2012).

The provision of steamed tofu is expected to help overcome sleeplessness disorders during the premenopausal period so that the quality of premenopausal women's sleep becomes better in addition to the choice of using tofu because it is easy to get and the public does not know the benefits of tofu in reducing sleeplessness disorders in the premenopausalperiod. Based on these problems, the authors are interested in researching "The Effect of Steamed Tofu On Sleep Quality in Premenopausal Women".

Methods. This type of research is preexperimental designs research with one group pretest posttestresearch. The population in this study was premenopausal women aged 45-50 years as many as 54 people who experienced symptoms of premenopause. The sampling technique in this study is purposive. So the size of the sample taken in this study is 48 premenopausal women aged $45-50$ years who experience premenopausal symptoms in Ngabean Village, Magelang Regency. To see the difference before and after the intervention is used Wilcoxon Test..

Result and Discussion.

\section{Premenopausal Women's Sleep Quality Before Intervention}

Table 1. Distribution of Quality of sleep before consuming processed steamed tofu

\begin{tabular}{llll}
\hline No. & Quality of sleep & Percentage & Frequency \\
\hline 1 & Good & $10,42 \%$ & 5 \\
2 & Bad & $89,58 \%$ & 43 \\
\hline & Jumlah & $100 \%$ & 48 \\
\hline
\end{tabular}

Based on Table 1, the distribution of sleep quality before consuming steamed tofu was found in the majority in the category of poor sleep quality, which was $89,58 \%$. The distribution of respondents' answers to the PSQI questionnaire obtained the most extreme results in the quite bad category. Respondents who started sleeping were found to be quite large who started sleeping at 22.00 WIB with a percentage of $43 \%$. For those who started falling asleep every night, it was found $>30$ minutes as much as $87 \%$. Calculation of the length of sleep at night the majority for 7 hours with a percentage of $46 \%$. Respondents who feel pain (limb) as much as 53\% (> 3x / week) or often occurs.

Premenopausal syndrome is experienced by many women who are about to enter menopause. Things that are often complained of include irregular menstruation, difficulty sleeping, experiencing heat from the neck to the chest at night, the body feels tired quickly (Proverawati \& Sulistyawati, 2017). Based on (Mulyani, 2013) the problem of insomnia will be experienced by some premenopausal women. In addition, premenopausal women will wake up at night and find it difficult to go back to sleep. In addition, difficulty sleeping is caused by low levels of serotonin which are affected in the premenopause period (Smith et al., 2018). Serotonin levels are affected by endorphins levels. Serotonin affects a person's mood, if levels in the body decrease, this will cause 
depression and difficulty sleeping (Mulyani, 2013).

The occurrence of anxiety, worry, and fear experienced during premenopause will cause sleep quality to decrease (Widyastuti, 2015). Then for those who experience limb pain due to lack of levels of the hormone estrogen which causes reduced calcium and collagen in the bones which will result in postmenopausal women being more at risk for osteoporosis and other physical disorders (Mulyani, 2013). The duration of sleep for $45-50$ years is 7 hours/day, when the duration of sleep is less than 7 hours the body has problems in the system (Hanifa et al., 2016). In the data, it was found that the amount of sleep at night was 7 hours, only $46 \%$

\section{Premenopausal Women's Sleep Quality After Intervention}

Table 2. Distribution of Sleep quality after consuming steamed tofu processed

\begin{tabular}{llll}
\hline No & Quality of sleep & Percentage & Frequency \\
\hline 1 & Good & $85,41 \%$ & 41 \\
2 & Bad & $14,59 \%$ & 7 \\
\hline & Jumlah & $100 \%$ & 48 \\
\hline
\end{tabular}

Based on Table 2. distribution of sleep quality after consuming processed steamed tofu obtained the majority in the category of good sleep quality $85.41 \%$. These results are based on respondents' answers as in the distribution of respondents' answers to the PSQI questionnaire, the most extreme results are in the pretty good category, which is $93 \%$. The results of the answer to the question at what time did the respondent start sleeping, there was a decrease to $9 \%$ who started sleeping at $22.00 \mathrm{WIB}$. For those who have started to fall asleep every night, there is a change to 20 minutes with a percentage of $57 \%$. The result of calculating the length of sleep at night is the majority for 8 hours with the percentage increasing to $59 \%$. Respondents who were unable to fall asleep for 30 minutes lying down experienced an increase in the percentage of the TP option (never) by $30 \%$. In the statement of difficulty breathing well, the percentage increased quite high in the TP option (never) by $54 \%$. Those who experience overheating at night have a very high increase in the TP option (never), which is $85 \%$. Meanwhile, those who experience nightmares in their sleep also have an increase in the TP choice (never) with a percentage of $89 \%$ and those who experience disturbances for other reasons also experience an increase in the TP choice (never) by $98 \%$.

From the data obtained after the intervention, progress or improvement was very good compared to before the intervention. It is proven that respondents who experience premenopausal symptoms by consuming isoflavone-rich foods in the form of tofu can improve their sleep quality. Sleep quality is a measure of the ease with which a person can initiate sleep and maintain sleep, the quality of a person's sleep can be described by the length of time he sleeps, and the complaints felt during sleep or after waking up (Burssens et al., 2011). In the table after the intervention, the dominant sleep duration was 8 hours and a decrease in other complaints that interfered with sleep. The amount of sleep needed for adulthood to middle-aged youth is 7-8 hours / day (Hidayat, 2008), with this, it can be concluded that good quality sleep in premenopause is 7 hours / day. If 8 hours/day it can still be categorized as good because the premenopause period is still in transitional periods. This significant increase was due to the consumption of processed steamed tofu for 14 days so that it had an effect on the body. Tofu is processed from soybeans. Soybean is one of the leguminous plants that is widely used as a basic ingredient for various types of food in East Asia such as soy sauce, tofu and tempeh (Wikayanti \& Panjaitan, 2019).

Soybeans are consumed by the community as a side dish and snack. Several types of processed foods derived from soybeans include tempeh, tofu, soy sauce, fried soybeans, soy flour, soy milk, boiled soybeans and peanut brittle. Soybean contains about $40 \%$ protein, $20 \%$ oil, $35 \%$ soluble carbohydrates (sucrose, stachyose, raffinose, etc.) and insoluble carbohydrates (dietary fiber), and 5\% ash. According to research conducted by (Cui et al., 2015) it was found that a high daily intake of isoflavones from food was significantly associated with optimal sleep duration (7-8 hours) and better sleep quality. When menopausal symptoms are resolved, premenopausal-menopausal women will be comfortable in their daily lives and their sleep quality will be good. From poor sleep quality to good, good sleep quality gets better with isoflavone consumption in their daily lives (Proverawati \& Sulistyawati, 2017; Koswara, 2006; Yulifianti et al., 2018). 


\section{The Effect Of Steamed Tofu Processed Administration On The Sleep Quality Of Premenopausal Women}

Bivariate analysis of this study was conducted to test the effect of steamed tofu processed administration on the sleep quality of premenopausal women. Bivariate analysis in this study uses non-parametric tests with Wilcoxon Test analysis because the data scale is categorical (ordinal). Bivariate analysis here will prove changes before and after intervention..

Table 3. The Effect Of Steamed Tofu Processed Administration On The Sleep Quality Of Premenopausal Women

\begin{tabular}{ll}
\hline \multicolumn{1}{c}{ The Effect } & \multicolumn{1}{c}{$\mathrm{n}$} \\
\hline Decrease & 48 \\
Increase & 0 \\
Permanent & 0 \\
\hline P value & 0,000 \\
\hline
\end{tabular}

In table 3 it was found that negative ranks or differences (negative) between the sleep quality results of premenopausal women aged 45-50 years for before intervention and after intervention were 48 negative data $(N)$ which means 48 respondents experienced a decrease from the score before the intervention to after the intervention. In the Positive Ranks or the difference (positive) between the sleep quality results of premenopausal women aged $45-50$ years for before intervention and after intervention is 0 . Ties are the similarity of values before intervention and after intervention, here the value of Ties is 0 , so it can be said that there is no equal value between before intervention and after intervention..

The Wilxocon test statistic quality of premenopausal women aged $45-50$ years obtained the $p$ value with alpha $5 \%$ or 0.05 value is about 0,000 . Supported by wilcoxon test results on the sleep quality of premenopausal women aged 45-50 years above showed that the $p$ value of the quality of sleep is worth 0,000 ( $p$ value $<0,05$ ) which means there is a significant influence of steamed tofu processed on the quality of sleep of premenopausal women aged $45-50$ years.

Steamed tofu contains $80 \mathrm{mg} / 100$ grams of isoflavones. Isoflavones are very instrumental in the quality of sleep in reducing premenopausal symptoms. Isoflavones are characterized by being estrogenic. The estrogenic properties of isoflavones are due to the $A-C$ ring resembling the $A-B$ ring in estrogen and similar to the hydroxyl group in position 5. Thus, it plays an important role in increasing estrogen activity. In menopause, isoflavones are estrogenic by taking over endogenous estrogen to bind to the estrogen receptor so that it has a positive effect on reducing complaints in premenopause to menopause which causes poor sleep quality (Purnomo, Rahayu, Hariyadi, \& Nuraida, 2011)

A similar study was conducted by (Hasnita et al., 2019) with the title "The Effect of Giving Processed Steamed Tempe to Symptoms of Hot Flush in Menopausal Women" with the results that there was an effect of giving processed steamed tempeh to hot flush symptoms in postmenopausal women with a significance value of 0.000 . In addition, according to research (Trinovelda \& Marita, 2018) with the title "The Effect of Soy Milk Consumption on Menopause Complaints" with a $p$ value of 0.001 ( $p$ value $<0.05$ ) which means that there is an effect of consumption of soy milk on decreasing menopause complaints. In a study (Zaki et al., 2018) it was found that there was an effect of giving soy milk to reducing hot flush symptoms in climacteric women.

The choice of soy-based ingredients here is because soybeans contain isoflavones. Isoflavones are one type of polyphenolic compound that has a structure that resembles estrogen so that it can give effects like estrogen. Isoflavones are also often referred to as phytoestrogen derivatives with estrogenic activity (Fawwaz et al., 2017). Isoflavones in tofu will work like the hormone estrogen in general in premenopausal and menopausal women, therefore it is called the estrogenic effect (Aquina \& Permatasari, 2012). In premenopausal women there are many changes that result in premenopausal syndrome in the form of hot flushes, night sweats, it can cause sleep disturbances that will affect the quality of the mother's sleep so that the mother wakes up from her sleep. Hot flushes and night sweats occur because the body of premenopausal women begins to experience a decrease in the hormone estrogen (Fawwaz et al., 2017). By consuming isoflavones, isoflavones will work to bind to estrogen receptors by influencing endogenous estrogen levels which will gradually increase estrogen levels with the aim of balancing 
hormones (Puspita Sari, 2019). What binds to the alpha $(\alpha)$ receptor is the phenolic ring on isoflavones which causes an estrogenic effect (Winarsih, 2010). This estrogenic effect arises because the $A-C$ ring on isoflavones is similar to the $A-B$ ring on the hormone estrogen, causing an estrogenic reaction in isoflavones that can act like estrogen (Purnomo, Rahayu, Hariyadi, Nuraida, et al., 2011). When estrogen starts to balance, there will be a balance in the serotonin hormone in the body which will stimulate endorphins to increase. When this happy hormone increases it will begin to minimize the anxiety that arises in premenopausal women and be replaced with happiness. When the body is spared from anxiety, the body will be easy to regulate metabolism so that premenopausal women will avoid having trouble sleeping, which will lead to increased sleep quality for premenopausal or menopausal women (Mulyani, 2013)

Conclusion and Suggestions. The sleep quality of premenopausal women aged 45-50 years before consuming processed steamed tofu was found in the majority in the category of poor sleep quality, which was $89,58 \%$. The sleep quality of premenopausal women aged 45-50 years after consuming processed steamed tofu was found in the majority in the category of good sleep quality, $85,41 \%$. There is a significant effect of the provision of processed steamed tofu on the sleep quality of premenopausal women aged $45-50$ years.

Suggestion for premenopausal women to consuming variations of processed steamed tofu (2x a day, with a dose of @ 100 grams or medium pieces) as a source of isoflavones in improving the quality of sleep for premenopausal and postmenopausal women who experience sleep deprivation/sleep disorders in the premenopausal period so that they can undergo pre-age with totality by consuming it regularly. Midwives socialize in the posyandu for the elderly about the effects of consuming steamed tofu or variations of steamed tofu (2x a day, with a dose of @100 grams or moderate pieces) as an alternative to reduce symptoms of premenopausal syndrome, especially related to sleep quality.

\section{References.}

Aquina, M., \& Permatasari, N. (2012). The Effectiveness Of Tofu Liquid Waste As A Natural Phytoestrogen For Mandibular
Bone Of Ovariectomized Rats. 1(1).

Ariyanti, H., \& Apriliana, E. (2016). Pengaruh Fitoestrogen terhadap Gejala Menopause. Jurnal Majority.

Burssens, S., Pertry, I., Diasolua, D., Kuo, Y.H., Van, M., \& Lambei, F. (2011). Soya, Human Nutrition and Health. In Soybean and Nutrition. https://doi.org/10.5772/21951

Cui, Y., Niu, K., Huang, C., Momma, H., Guan, L., Kobayashi, Y., Guo, H., Chujo, M., Otomo, A., \& Nagatomi, R. (2015). Relationship between daily isoflavone intake and sleep in Japanese adults: a cross-sectional study. Nutrition Journal, December. https://doi.org/10.1186/s12937-015-0117$x$

Desi N.T.Idris, Fidiana K, Y. A. (2016). Description of women of women in insomnia components rating scale. Vol 2 No 1 (2016): Jurnal Penelitian Keperawatan.

https://doi.org/https://doi.org/10.32660/jur nal.v2i1.147

Fawwaz, M., Natalisnawati, A., \& Baits, M. (2017). Determination of Isoflavon Aglicone in Extract of Soymilk and Tempeh. Industria: Jurnal Teknologi Dan Manajemen Agroindustri, 6(3), 152-158. https://doi.org/10.21776/ub.industria.2017 .006.03.6

Hanifa, A., Kedokteran, F., IImu, D. A. N., Islam, U., \& Syarif, N. (2016). Hubungan kualitas tidur dan fungsi kognitif pada lanjut usia di panti sosial margaguna jakarta selatan.

Hasnita, E., Sulung, N., \& Novradayanti, N. (2019). Pengaruh Pemberian Olahan Tempe Kukus Terhadap Gejala Hot Flashes Pada Ibu Menopause. Jurnal Endurance, $4(3), 496$. https://doi.org/10.22216/jen.v4i3.4581

Mulyani, N. S. (2013). MENOPAUSE Akhir Siklus Menstruasi pada Wanita di Usia Pertengahan (cetakan ke). Nuha Medika.

Proverawati, A \& Sulistyawati, E. (2017). MENOPAUSE dan Sindrome Premenopause (W. Kristiyanasari (ed.); 2nd ed.). Nuha Medika.

Purnomo, E. H., Rahayu, W. P., Hariyadi, P., \& Nuraida, L. (2011). Effect of Sterilization Dosage, Medium , and Tempeh Thickness on Physical Properties and Nutrition Value of Canned Tempeh. The 12 Th ASEAN 
Food Conference, PD-261(BITEC Bangna, Bangkok, Thailand).

Puspita Sari, R. D. (2019). Pemanfaatan Isoflavon Dengan Bahan Dasar Kulit Kopi Robusta Dengan Penanda BMD (Bone Marrow Density) Pada Wanita Peri/Post Menopause. Biomedical Journal of Indonesia: Jurnal Biomedik Fakultas Kedokteran Universitas Sriwijaya, 5(3), 100-105.

https://doi.org/10.32539/bji.v5i3.8684

Smith, R. L., Flaws, J. A., \& Mahoney, M. M. (2018). Factors Associated with Poor Sleep During Menopause: Results from the Midlife Women's Health Study. Physiology \& Behavior, 45(1), 98-105. https://doi.org/10.1016/j.sleep.2018.01.01 2

Trinovelda, N. I., \& Marita, E. (2018). Pengaruh Susu Kedelai dalam Meringankan Gejala Sindrom Premenstruasi pada Remaja Puteri. Jurnal IImiah Keperawatan Sai Betik, 14(1), 49. https://doi.org/10.26630/jkep.v14i1.1007

Widyastuti, Y. (2015). Hubungan antara kualitas tidur lansia dengan tingkat kekambuhan pada pasien hipertensi di klinik dhanang husada sukoharjo (Issue Juli). STIKES KUSUMA HUSADA SURAKARTA

Wikayanti, R. A., \& Panjaitan, A. P. (2019). PENGARUH PEMBERIAN KEDELAI TERHADAP SISTEM REPRODUKSI. Jurnal Penelitian Perawat Profesional, 1(November), $\quad$ 89-94. http://jurnal.globalhealthsciencegroup.co m/index.php/JPPP/article/download/83/65

Winarsih, H., Purwanto, A., \& Dwiyanti, D. H. (2010). Kandungan Protein dan Isoflavon pada Kedelai dan Kecambah Kedelai $A$ Study on Protein and Isoflavone Content of the Soy and Soy Germ. 15(2), 181-187.

Yulifianti, R., Muzaiyanah, S., \& Utomo, J. S. (2018). Kedelai sebagai Bahan Pangan Kaya Isoflavon. Buletin Palawija, 16(2), 84. https://doi.org/10.21082/bulpa.v16n2.201 8.p84-93

Zaki, M., Ferusgel, A., Maya, D., \& Siregar, S. (2018). Efektifitas Susu Kedelai Terhadap Penurunan Gejala Hot Flush Pada Wanita Klimakterium. 1(2), 85-92 